\title{
The Response of Several Citrus Genotypes to High-salinity Irrigation Water
}

\author{
Y. Levy ${ }^{1}$ and J. Lifshitz \\ Agricultural Research Organization, Gilat Experiment Station, Mobile Post \\ Negev2, 85-280 Israel

\section{Y. De Malach and Y. David} \\ Ramat haNegev Desert Agro-Research Center, Mobile Post Chalutza, \\ Israel
}

Additional index words. Cleopatra mandarin, Citrus reshni, Gou Tou Cheng, C. aurantium hybrid?, Rangpur, C. limonia, RT803, C. limonia $\times$ (C. sinensis $\times$ Poncirus trifoliata), sour orange $C$. aurantium, SB812, C. sunki x Poncirus trifoliata, rootstock, chloride, sodium, stress

\begin{abstract}
The effect of irrigation with saline water on several citrus genotypes was evaluated in a short-term field experiment. Salinity levels ranged from 2.0 to $6.4 \mathrm{dS} \cdot \mathrm{m}^{-1}$. Comparatively salt-tolerant Citrus species and Citrus $\mathbf{x}$ Poncirus hybrids were tested for their possible use as rootstocks for commercial citrus cultivars irrigated with brackish water. All the tested genotypes survived the highest salinities. At all salinity levels, the best chloride excluder was Cleopatra mandarin (Citrus reshni Hort. ex Tan.), and the worst was sour orange ( $C$. aurantium L.). Gou Tou Cheng ( $C$. aurantium hybrid?) and Rangpur $(C$. limonia Osb.) $\times$ Troyer citrange (C. sinensis $\mathrm{L} . \times$ Poncirus trifoliata $\mathrm{L}$.) RT803 were found to be promising genotypes for further evaluation as rootstocks tolerant to high salinities. Rangpur was unsuitable because of foot rot.
\end{abstract}

Citrus is a salt-sensitive crop. Like many woody fruit crops, it can accumulate $\mathrm{Cl}^{-}$or $\mathrm{Na}^{+}$, or both, to toxic levels in plant tissues (Bernstein, 1980; Mass, 1996; Shalhevet and Levy, 1990). Oppenheimer (1937) was the first to report the effect of saline water on citrus rootstocks. Mature orange trees on sour orange (SO) rootstock accumulated less $\mathrm{Cl}^{-}$in the scion leaves than did trees on Palestine sweet lime (C. limettioides Tan.). Irrigation with saline water did not lead to the accumulation of $\mathrm{Na}$ in the scion regardless of rootstock. Later studies, mainly on potted seedlings (Cooper and Gorton, 1952), ranked the rate of $\mathrm{Cl}^{-}$uptake among the citrus genotypes. Cleopatra mandarin (CLEO) and Rangpur (RANG) accumulated $\mathrm{Cl}^{-}$at a "slow rate," and rough lemon ( $C$. jambhiri Lush.) and SO at a "medium rate." These results were later confirmed in many other studies (Francois and Clark, 1980; Zekri and Parsons, 1992). The response of field-grown trees differs from that

Received for publication 16 July 1998. Accepted for publication 27 Jan. 1999. Contribution No 204/98 from the Agricultural Research Organization (ARO), Institute of Horticulture, Bet Dagan, Israel. We thank Dr. A. Genizi of the Dept. of Statistics, ARO, for helpful discussions and suggestions; and our colleagues Drs. J. Shachak, A. Shaked, and J. Shalhevet for helpful comments. We are grateful to M. Aaron for his assistance with this work.The cost of publishing this paper was defrayed in part by the payment of page charges. Under postal regulations, this paper therefore must be hereby marked advertisement solely to indicate this fact.

${ }^{1}$ To whom reprint requests should be addressed. E. mail address: vfjlev@ias.agri.gov.il of potted seedlings (Levy and Shalhevet, 1990, 1991). For mature, fruit-bearing trees, there was a small advantage to CLEO over SO, while rough lemon rootstock was very saltsensitive. The difference in response between potted seedlings and field-grown trees may be attributed to the distinction between pot-bound root systems, or sand culture (Zekri and Parsons, 1992), and the root systems of fieldgrown trees. CLEO and RANG remain the best salt-tolerant rootstocks available. Improved citrus tristeza virus (CTV)-tolerant rootstocks, with tolerance to salinity similar to or better than SO, are needed.

Salinity data on fruit and nut trees are scarce because of the long-term and complex nature of the research (Mass, 1996). The method of double-emitter source (DES; De Malach et al., 1996) provides a new tool for achieving a salinity gradient, and can be used to study the response of different genotypes to salinity under orchard conditions. In this study, we compared new, apparently CTV- and salinity-tolerant genotypes for their possible use as rootstocks in citrus orchards irrigated with brackish water.

\section{Materials and Methods}

Plant material. The genotypes that were studied in this work were: CLEO; Gou Tou Cheng (GT); RANG; SO; Rangpur x Troyer (RT803), originally named C-54-64-32; Sunki $x$ Benecke (SB812), originally named C-65165; and, later, HRS812. Both crosses were made by J. Furr in Indio, Calif. (Furr and Ream, 1969).
Most RANG trees died from attack by Phytophthora and are therefore not included in this report. This is not surprising, since in Israel RANG, more than any commercial rootstock, may become infected with foot rot, which is not detected in the nursery but becomes severe after transplanting (Levy et al., 1980).

Location. One-year-old seedlings of the different genotypes were planted in the field at the Ramat haNegev Desert Agro-Research Center at $31^{\circ} 05^{\prime} \mathrm{N}$ and $34^{\circ} 41^{\prime} \mathrm{E}$, elevation $\approx 300 \mathrm{~m}$, and mean annual rainfall (winter only) $<100 \mathrm{~mm}$. The soil is light loess (eolian sandy loam) with $5 \%$ to $8 \%$ clay and a $\mathrm{pH}$ of $8.0-8.4$.

Experimental design. Four salinities were applied with DES (De Malach et al., 1996) at increasing levels along the rows. Salinity ranged from 2.0 to $6.4 \mathrm{dS} \cdot \mathrm{m}^{-1}$ in four linear steps. Each salinity level was applied to groups of three plants in each row. With no buffer trees between the different salinity treatments, the first tree at a given salinity was partially influenced by the salinity of the previous treatment, while the last was affected by the subsequent treatment, actually producing a linear salinity gradient. The salinity gradients were replicated in two blocks, with the salinity vectors (increase in salinity) in opposing directions. The genotypes were planted in parallel rows, with a total of six plants for each salinity. The plants were drip irrigated and fertigated three times a week. The salinity regime was imposed from the day of planting and the data presented here were collected after two summers of salinization.

Water. The local well water (highest salinity) had an electrical conductivity $\left(\mathrm{EC}_{\mathrm{i}}\right)$ of 6.4 $\mathrm{dS} \cdot \mathrm{m}^{-1}$; ions $\left(\mathrm{mol} \cdot \mathrm{m}^{-3}\right)$ were: $47.3 \mathrm{Cl}^{-}, 44.4$ $\mathrm{Na}^{+}, 4.5 \mathrm{Ca}^{++}, 3.5 \mathrm{Mg}^{++}, 4.5 \mathrm{SO}_{4}^{--}$, and 5.0 $\mathrm{HCO}_{3}^{-}$.

Measurements. Observations, measurements, and chemical analyses were made on individual trees. A running mean of three trees was used to analyze the plant response, and a similar running mean was calculated for the $\mathrm{EC}_{\mathrm{i}}$ values.

Twenty spring-flush leaves were collected from each tree at the end of September. Leaves were weighed within $3 \mathrm{~h}$ of collection, washed in dilute detergent (Nonidet; BDH Co., Poole, England), and dried in a ventilated oven at 65 ${ }^{\circ} \mathrm{C}$. Pulverized leaf material $(100 \mathrm{mg})$ was shaken for $>4 \mathrm{~h}$ in $5 \mathrm{~mL}$ of water; $\mathrm{Cl}^{-}$was determined with a chloride meter, and total $\mathrm{Na}$ and $\mathrm{K}$ with a flame photometer.

Thresholds and slopes of the effect of salinity on growth were calculated by nonlinear analysis (PROC NLIN; SAS Inst., 1985)

\section{Results and Discussion}

Seedlings of all genotypes survived the highest salinity level with no apparent toxicity symptoms such as leaf-burn, chlorosis, or defoliation. Growth of all genotypes was reduced at a similar rate (slope) as salinity increased regardless of their $\mathrm{Cl}^{-}$or Na uptake (Fig. 1). Similar results were reported earlier (Garcia-Legaz et al., 1993; Syvertsen et al., 1993; Zekri and Parson, 1989, 1990). How- 


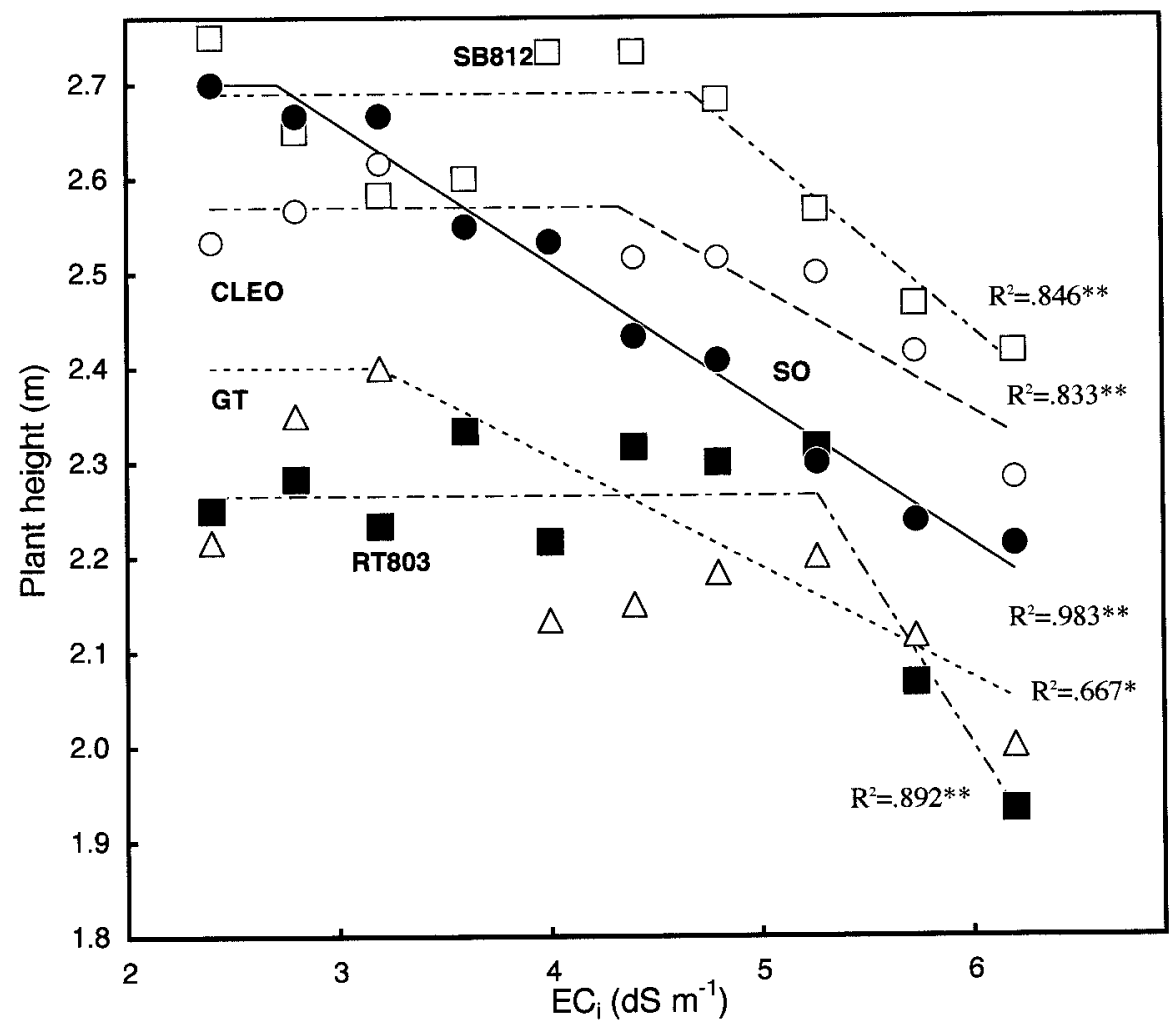

Fig. 1. The effect of irrigation water salinity $\left(\mathrm{EC}_{\mathrm{i}}\right)$ on tree height of seedlings of five Citrus genotypes. Lines were calculated by nonlinear (NLIN) procedure. GT lines did not converge, height was reduced from $2.3 \mathrm{~m}$ at a threshold of $3.2 \mathrm{dS} \cdot \mathrm{m}^{-1}$ at a rate (slope) of $-2.71 \%$ per dS $\cdot \mathrm{m}^{-1}$. CLEO height was reduced from $2.6 \pm 0.02 \mathrm{~m}$ at a threshold of $4.34 \pm 0.32 \mathrm{dS} \cdot \mathrm{m}^{-1}$, slope $=-2.98 \pm 0.73 \%$ per dS $\cdot \mathrm{m}^{-1}$. Height of SB812 was reduced from $2.7 \pm 0.02 \mathrm{~m}$ at a threshold of $4.68 \pm 0.27 \mathrm{dS} \cdot \mathrm{m}^{-1}$, slope $=-4.04 \pm 1.03 \%$ per dS $\cdot \mathrm{m}^{-1}$. Height of SO was reduced from $2.7 \pm 0.30 \mathrm{~m}$ at a threshold of $2.72 \pm 0.21 \mathrm{dS} \cdot \mathrm{m}^{-1}$, slope $=-5.43 \pm 0.30 \%$ per dS $\cdot \mathrm{m}^{-1}$. RT lines did not converge, height was reduced from $2.3 \mathrm{~m}$ at a threshold of $5.27 \mathrm{dS} \cdot \mathrm{m}^{-1}$, slope $=-6.83 \%$ per $\mathrm{dS} \cdot \mathrm{m}^{-1}$.

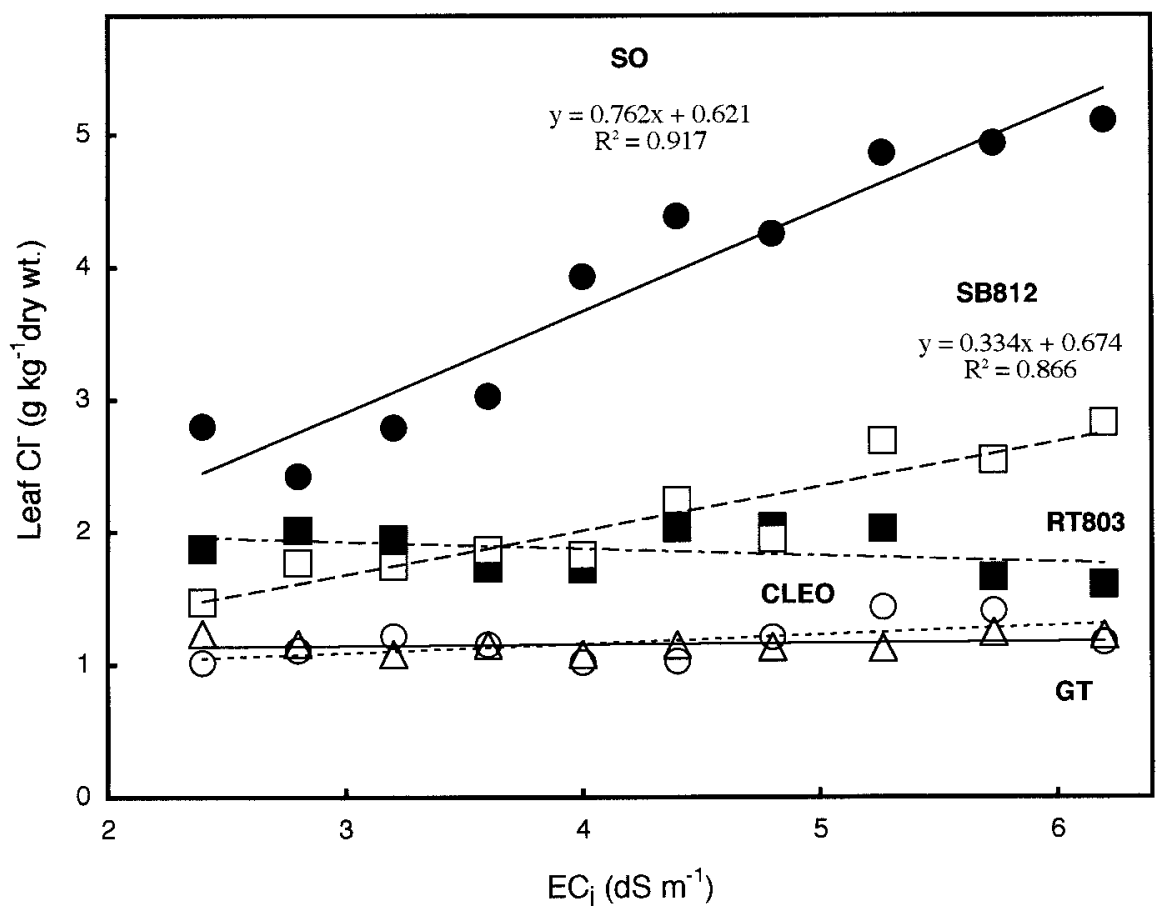

Fig. 2. The effect of $\mathrm{EC}_{\mathrm{i}}$ on the concentration of $\mathrm{Cl}^{-}$in leaf dry matter of five Citrus genotypes. ever, the thresholds were not the same for all genotypes. SO had the lowest threshold and RT803 and SB812 the highest. The regression was poor in GT, because of the large variability typical for this genotype. Growth can be hampered by low osmotic potential of the soil solution, as with most plants, in addition to the effect of specific ion toxicity (Maas, 1993).

The most $\mathrm{Cl}^{-}$-tolerant genotypes were CLEO and GT (Fig. 2). Most of the new genotypes proved better than SO in terms of leaf $\mathrm{Cl}^{-}$accumulation and growth. These genotypes are candidates to replace SO as a rootstock, but should be tested thoroughly for their disease tolerance and effects on yields, fruit quality, and longevity.

The concentrations of $\mathrm{Cl}^{-}$in leaves of nongrafted genotypes were relatively low ( $<6 \mathrm{~g} \cdot \mathrm{kg}^{-1}$ dry weight), in comparison with levels found in mature grafted citrus trees (Levy and Shalhevet, 1990, 1991; Shalhevet and Levy, 1990). GT, RT803, and CLEO did not accumulate much $\mathrm{Cl}^{-}$. The genotype that accumulated most $\mathrm{Cl}^{-}$was $\mathrm{SO}$, which, in a mature orchard, proved relatively tolerant to salinity (Levy et al., 1992).

The level at which $\mathrm{Cl}^{-}$accumulation in the leaves becomes toxic is not clear. Cole (1985) reported that concentrations $>2.5 \mathrm{~g} \cdot \mathrm{kg}^{-1}$ dry weight in 'Valencia' orange on rough lemon reduced yield. Chapman (1968) suggested 7.5 $\mathrm{g} \cdot \mathrm{kg}^{-1} \mathrm{Cl}^{-}$as the maximum permissible level. Furr and Ream (1969), however, reported no leaf burn at concentrations $<20 \mathrm{~g} \cdot \mathrm{kg}^{-1}$. Similar results were obtained in mature trees in the Negev desert of Israel, where relatively high $\mathrm{Cl}^{-}$levels in the leaves did not cause leaf burn, but did cause premature (green) leaf abscission. High $\mathrm{Cl}^{-}$concentration in leaf tissue may damage citrus, which is apparent in the loss of chlorophyll (bronzing). This damage and the reduction in photosynthesis are well documented (Carter and Myers, 1963; Garcia-Legaz et al., 1993; Lloyd et al., 1987; Romero-Aranda and Syvertsen, 1996; Zekri, 1991). The reduction in photosynthesis may inhibit growth and lead to autumn and winter defoliation. The cumulative deleterious effect of salinity can result in $\mathrm{Cl}^{-}$levels $>20 \mathrm{~g} \cdot \mathrm{kg}^{-1}$ leaf dry weight and reduce yield significantly after 2 to 3 years, especially in high-yielding species such as grapefruit (C. paradisi Macf.) (Levy and Shalhevet, 1990).

In this study, a significant negative correlation was found between leaf $\mathrm{Cl}^{-}$concentration and growth of SO and SB812 (Fig. 3). Concentrations above $2 \mathrm{~g} \cdot \mathrm{kg}^{-1}$ were harmful for SO and SB812 seedlings, in contrast with mature trees grafted on SO (Levy and Shalhevet, 1990).

The ultimate productivity (fruit yield and quality) of citrus on these rootstocks will depend on the interactions of many factors, including cultivar-rootstock compatibility, cultural practices, tree age, and edaphic conditions. However, nongrafted genotypes that did not accumulate $\mathrm{Cl}^{-}$for 2 years at extreme salinity levels, should tolerate salinity better than genotypes such as SO, which accumulated $\mathrm{Cl}^{-}$as salinity levels increased. The low osmotic potential associated with increased 
$\mathrm{EC}_{\mathrm{i}}$ will probably reduce the growth of such $\mathrm{Cl}^{-}$-tolerant trees, as it does in most field crops (Fig. 1). However, it will not cause the total collapse of trees because of accumulation of $\mathrm{Cl}^{-}$to toxic levels.

The best $\mathrm{Cl}^{-}$excluding genotypes were CLEO, GT and RT803. Results obtained for RT803 were not expected, since it is a hybrid of Troyer citrange. The latter ranks among the most $\mathrm{Cl}^{-}$-sensitive genotypes (Levy and Lifshitz, 1995; Levy and Shalhevet, 1990). Both SO and SB812 accumulated $\mathrm{Cl}^{-}$as salinity increased. In terms of $\mathrm{Cl}^{-}$exclusion, SB812 performed better than did SO when data were expressed on a dry weight basis (Fig. 2).

The relative success of Poncirus crosses with the salinity-tolerant Rangpur and Sunki is encouraging. This proves the feasibility of selecting better salt-tolerant rootstocks from crosses of Poncirus with relatively salt-tolerant Citrus species, especially CLEO. However, regardless of their salinity and CTV tolerance, some of these crosses may be susceptible to citrus viroids (Levy, 1997) or to Phytophthora (Furr and Ream, 1969).

Along with $\mathrm{Cl}^{-}, \mathrm{Na}^{+}$is another toxic ion that can accumulate in leaves under saline conditions. CLEO accumulated more $\mathrm{Na}$ than did other genotypes (Fig. 4), as in previous studies (Cooper and Shull, 1953; Levy and Shalhevet, 1990; Levy et al., 1992; Taylor and Dimsey, 1993). The lack of adverse effects of $\mathrm{Na}$ may be linked to the high-pH, calcareous soil in this experiment. In sand culture, potted CLEO plants may suffer more than other rootstocks from salinity (Syvertsen et al., 1988). As a rootstock, CLEO performed better than did SO, which had lower levels of leaf $\mathrm{Na}$, during a long-term experiment using the scions 'Marsh' grapefruit and 'Washington Navel' orange (Levy et al., 1992). CLEO is still the best $\mathrm{Cl}^{-}$excluding rootstock ever found for citrus, and usually the best choice for $\mathrm{Cl}^{-}$ salinity conditions, although not for salinity caused by $\mathrm{Na}_{2} \mathrm{SO}_{4}$ and $\mathrm{MgSO}_{4}$.

\section{Conclusions}

The results obtained in this experiment give hope that commercial citrus irrigation with brackish water may be feasible in the future, by using some of the genotypes investigated in this study. Among the new genotypes, SB812 absorbed some $\mathrm{Cl}^{-}$but less than did SO. This genotype is promising as a rootstock in Florida (H. Wutscher, personal communication, 1998) and in Israel. GT is a candidate to replace $\mathrm{SO}$, because of its tolerance to severe exotic isolates of CTV (Garnsey, 1993) and its apparent similarity to SO. Initial observations indicate that the growth rate of young orange trees grafted on it is as slow as those on CLEO, but significantly higher than on SO (Levy et al., 1996). The percentage of nucellar seeds may be low, and careful selection of seedlings will be needed in the nursery in order to achieve uniform trees. RT803 showed good tolerance to accumulation of both $\mathrm{Cl}^{-}$and $\mathrm{Na}$, even though it is a hybrid of Troyer citrange, but little is known about its performance as a rootstock. Hopefully it inherited from its Troyer

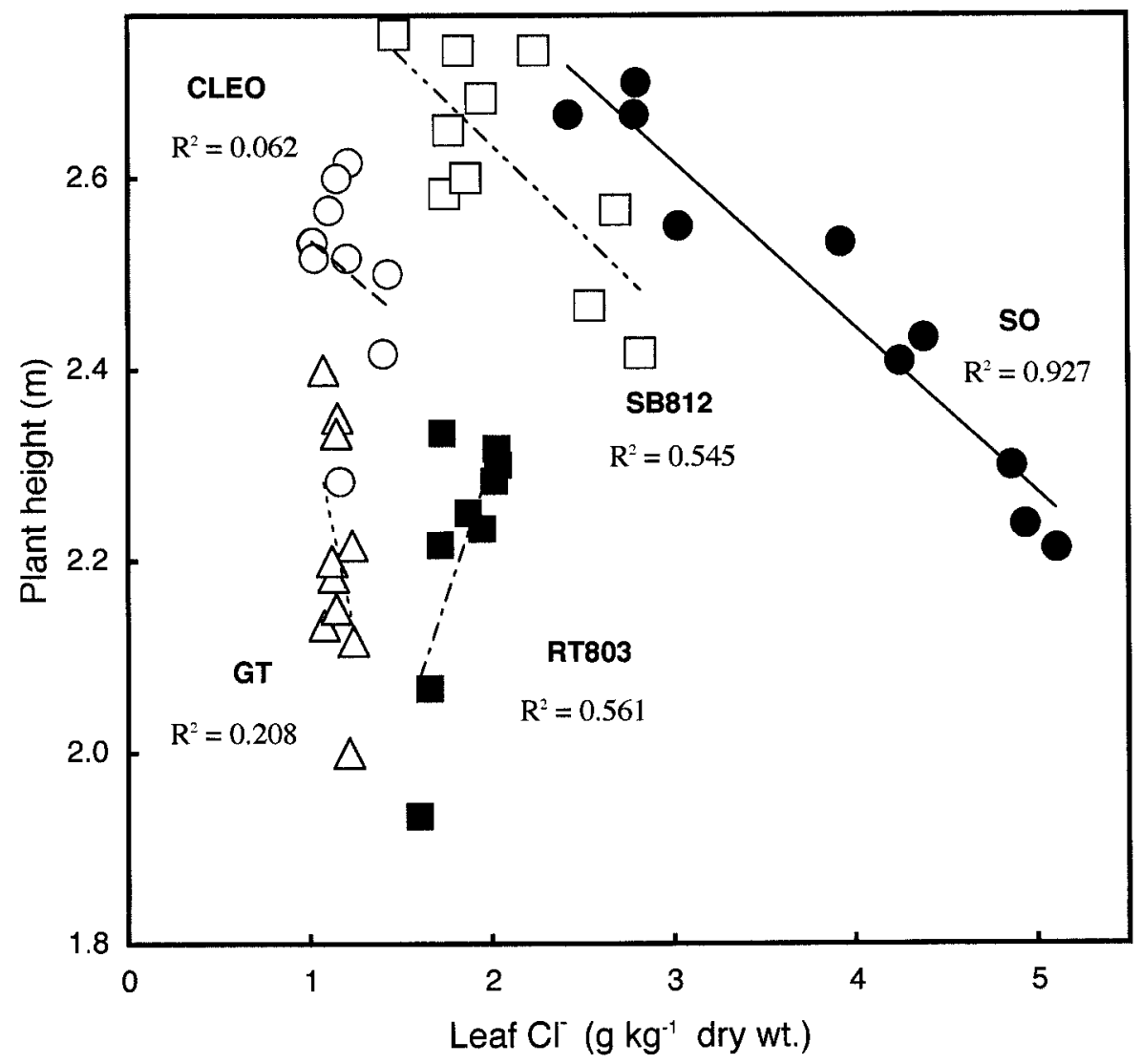

Fig. 3. Regression line models of tree height vs. concentration of $\mathrm{Cl}^{-}$in leaf dry matter of five Citrus genotypes (only significant regression formulas are presented).

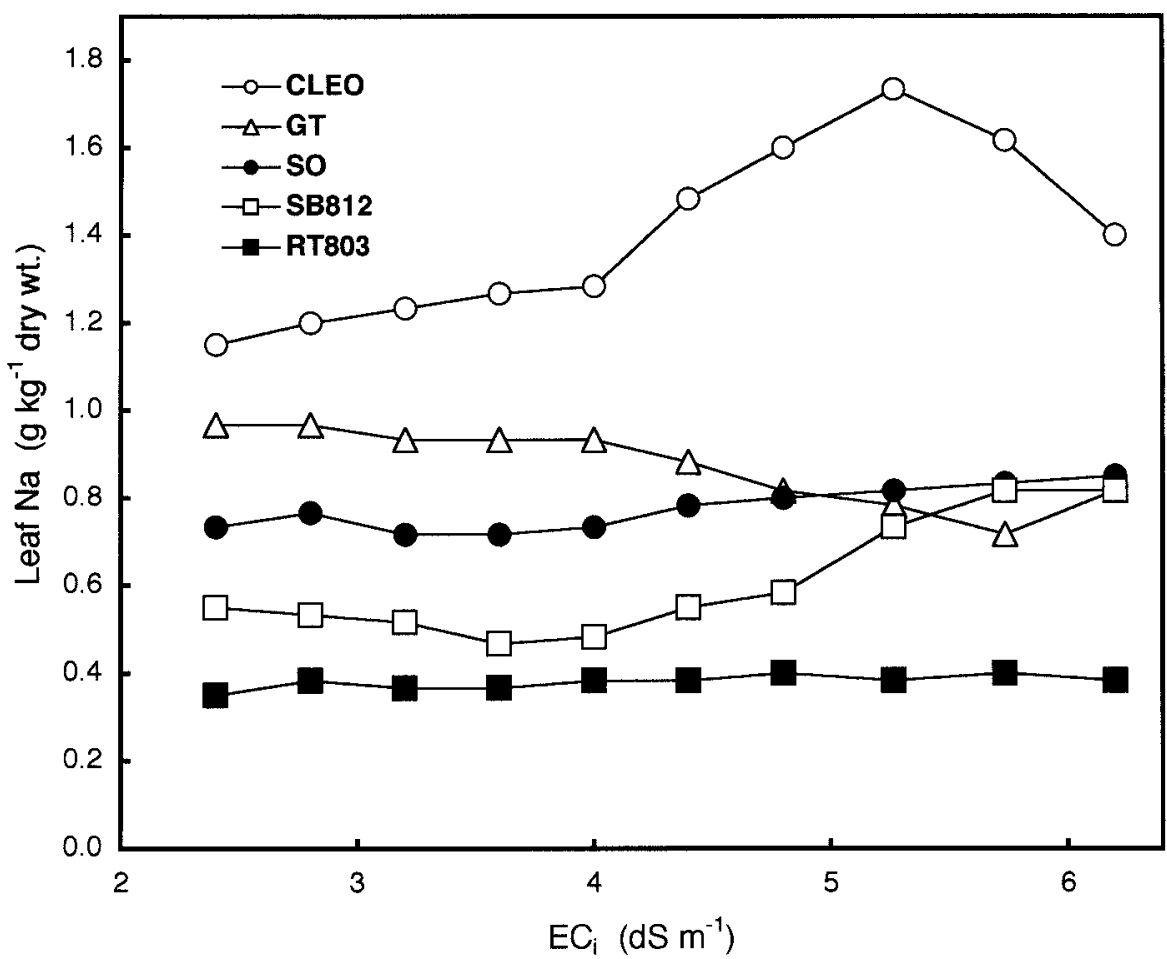

Fig. 4. The effect of $\mathrm{EC}_{\mathrm{i}}$ on the concentration of $\mathrm{Na}$ in leaf dry matter of five Citrus genotypes. 
parent resistance to Phytophthora and the ability to induce high fruit quality. Unlike reports from Texas (H. Wutscher, personal communication, 1998), it did not suffer from foot rot, which killed most of the Rangpur trees in our experiment.

Long-term rootstock-scion evaluation, which may require 10-20 years, will be needed to confirm these findings. One such experiment, employing an improved salinity gradient system and grafted trees, was planted in 1966 (Levy and Lifshitz, 1999). Long-term rootstock-salinity studies with commercial cultivars are needed to establish the economic basis for the utilization of brackish water for citrus.

Breeding of rootstocks should introduce new salinity-tolerant hybrids that will perform better than does CLEO. These genotypes can be tested for their salt tolerance in situ in shortterm field experiments similar to the one reported here.

\section{Literature Cited}

Bernstein, L. 1980. Salt tolerance of fruit crops. U.S Department of Agr. Info. Bul. 292 (revised).

Carter, D. and V. Myers. 1963. Light reflectance and chlorophyll and carotene contents of grapefruit leaves as affected by $\mathrm{Na}_{2} \mathrm{SO}_{4}, \mathrm{NaCl}$ and $\mathrm{CaCl}_{2}$. Proc. Amer. Soc. Hort. Sci. 82:217-221.

Chapman, H.D. 1968. The mineral nutrition of citrus, p. 200-247. In: W. Reuther, L.D. Batchelor, and H.J. Webber (eds.). The citrus industry, vol. 2. Univ. of California, Berkeley.

Cole, P.J. 1985. Chloride toxicity in citrus. Irrig. Science 6:63-71.

Cooper, W.C. and B.S. Gorton. 1952. Toxicity and accumulation of chloride salts in citrus on various rootstocks. Proc. Amer. Soc. Hort. Sci. 59:143-146.

Cooper, W.C. and A.V. Shull. 1953. Salt tolerance and accumulation of sodium and chloride ions in grapefruit on various rootstocks grown in naturally saline soil. Proc. Rio Grande Valley Hort. Soc. 7:107-117.

De Malach, Y., J. Ben-Asher, M. Sagi, and A. Alert. 1996. Double-emitter source (DES) for irriga- tion experiments in salinity and fertilization. Agron. J. 88:987-990.

Francois, I.E. and R.A. Clark. 1980. Salinity effects on yield and fruit quality of 'Valencia' orange. J. Amer. Soc. Hort. Sci. 105:199-202.

Furr, J.R. and C.L. Ream. 1969. Breeding citrus rootstocks for salt tolerance. Proc. 1st Intl. Citrus Symp., Riverside, Calif. 1:373-380.

Garcia-Legaz, M.F., J.M. Ortiz, A. Garcia-Lidon, and A. Cerda. 1993. Effect of salinity on growth, ion content and $\mathrm{CO}_{2}$ assimilation rate in lemon varieties on different rootstocks. Physiol. Plant. 89:427-432.

Garnsey, S.M. 1993. Tolerance of Gou Tou rootstock to severe exotic isolates of citrus tristeza virus (CTV). Proc. Fla. State Hort. Soc. 105:3538.

Levy, Y. 1997. The response of different rootstocks to viroid-infected scions. Proc. Congress Intl. Soc. Citrus Nurserymen, Montpelier, France. p. 261-265.

Levy, Y., P. Brosh, S. Ben-Anat, J. Lifshitz, M. Aaron, and A. Gotfried. 1996. Citrus cultivars and rootstocks for the Negev (in Hebrew). Agr. Res. Org., Gilat Expt. Sta. Rpt. 075-201.

Levy, Y. and J. Lifshitz. 1995. Alemow (Citrus macrophylla Wester), compared with six other rootstocks for nucellar 'Minneola' tangelo (Citrus paradisi Macf. $\mathrm{x}$ Citrus reticulata Blanco.). Scientia Hort. 61:131-137.

Levy, Y. and J. Lifshitz. 1999. Field screening of citrus rootstocks using trickle linear salinity gradient. Acta Hort. (In press.)

Levy, Y. and J. Shalhevet. 1990. Ranking the salt tolerance of citrus rootstocks by juice analysis. Scientia Hort. 45:89-98.

Levy, Y. and J. Shalhevet. 1991. Response of mature orange and grapefruit trees to irrigation with saline water, interactions with rootstock. Proc. Intl. Citrus Symp. Intl. Academic Publishers, Beijing 1:419-429.

Levy, Y., A. Shaked, and S. Ashkenazi. 1980. Tree development, yield and leaf nutrient levels of old-clone lemon trees on eight rootstocks. Expt. Agr. 16:49-55.

Levy, Y., J. Shalhevet, and J. Lifshitz. 1992. The effect of salinity on citrus rootstocks and scions. Proc. Intl. Soc. Citricult. VII Intl. Citrus Congress, Catania, Italy. 1:391-396.

Lloyd, J., J.P. Syvertsen, and P.E. Kriedemann. 1987. Salinity effects on leaf water relations and gas exchange of 'Valencia' orange, Citrus sinensis (L.) Osbeck, on rootstocks with different salt exclusion characteristics. Aust. J. Plant Physiol. 14:605-617.

Maas, E.V. 1993. Salinity and citriculture. Tree Physiol. 12:195-216.

Mass, E.V. 1996. Plant Response to soil salinity, p. 385-391. In: $4^{\text {th }}$ Natl. Conf. and Wkshp. on the Productive Use and Rehabilitation of Saline Lands, Albany, W. Australia. Promaco Conventions Ltd.

Oppenheimer, H.R. 1937. Injurious salts and the ash composition of fruit trees. Hadar 10:3-16.

Romero-Aranda, R. and J.P. Syvertsen. 1996. The influence of foliar-applied urea nitrogen and saline solutions on net gas exchange of Citrus leaves. J. Amer. Soc. Hort. Sci. 121:501-506.

SAS Institute. 1985. SAS user's guide: Statistics. version 5. SAS Inst., Cary, N.C.

Shalhevet, J. and Y. Levy, 1990. Citrus trees, p. 951-986. In: A.R. Stewart and D.R. Nielsen (eds.). Irrigation of agricultural crops. Agron. Monogr. 30. Amer Soc. Agron., Crop Sci. Soc. Amer. and Soil Sci. Soc. Amer., Madison, Wis.

Syvertsen, J.P., J. Lloyd, and J.P. Kriedemann. 1988. Salinity and drought stress effects on foliar ion concentration, water relations, and photosynthetic characteristics of orchard citrus. Aust. J. Agr. Res. 39:619-627.

Syvertsen, J.P., M.L. Smith, and B.J. Boman. 1993. Tree growth, mineral nutrition and nutrient leaching losses from soil of salinized citrus. Agr. Ecosystems and Environ. 45:319-334.

Taylor, B.K. and R.T. Dimsey. 1993. Rootstock and scion effects on the leaf nutrient composition of citrus trees. Aust. J. Expt. Agr. 33:363-371.

Zekri, M. 1991. Effects of $\mathrm{NaCl}$ on growth and physiology of sour orange and Cleopatra mandarin seedlings. Scientia Hort. 47:305-315.

Zekri, M. and L.R. Parsons. 1989. Growth and root hydraulic conductivity of several citrus rootstocks under salt and polyethylene glycol stresses. Physiol. Plant. 77:99-106.

Zekri, M. and L.R. Parsons. 1990. Calcium influences growth and leaf mineral concentration of citrus under saline conditions. HortScience 25:784-786.

Zekri, M. and L.R. Parsons. 1992. Salinity tolerance of citrus rootstocks: Effects of salt on root and leaf mineral concentrations. Plant Soil 147:171181. 